\title{
Comparing the Effects of Four Instructional Treatments on EFL Students' Achievement in Writing Classified Ads
}

\author{
Farzaneh Khodabandeh ${ }^{1}$ \\ ${ }^{1}$ Department of Linguistics and Language Teaching, Payame Noor University, Tehran, Iran \\ Correspondence: Farzaneh Khodabandeh, Department of Linguistics and Language Teaching, Payame Noor \\ University, PO box 19395-3697 Tehran, Iran. E-mail: farzaneh.khodabandeh@gmail.com
}

Received: November 29, 2015 Accepted: February 10, $2016 \quad$ Online Published: February 14, 2016

doi: 10.5539/elt.v9n3p139 URL: http://dx.doi.org/10.5539/elt.v9n3p139

\begin{abstract}
The current study set out to compare the effect of traditional and non-traditional instructional treatments; i.e. explicit, implicit, task-based and no-instruction approaches on students' abilities to learn how to write classified ads. 72 junior students who have all taken a course in Reading Journalistic Texts at the Payame-Noor University streamed by performing a TOEFL proficiency test. The selected participants were randomly divided into the following four groups; an explicit group which received direct instruction; an implicit group which were instructed indirectly, and the self-study group with no-instruction treatment in comparison to the task-based group which were asked to prepare a classified ad. A pre-test and a post-test were administered before and after the treatment. The moves in classified ads pre- and post- tests were analyzed through descriptive and inferential statistics. The quantitative analysis of the post-tests revealed that the explicit and task-based groups outperformed the implicit and self-study instruction groups. The findings of this research offer English teachers the chance to reconsider their practices and performances through the advantages and disadvantages of the traditional and new techniques which were employed in the current research and combine them to help learners improve their reading and writing skills.
\end{abstract}

Keywords: classified ads, distance educational system, genre-based instruction, lexical features, social media

\section{Introduction}

Reading news on social media or newspapers in modern societies, has become a daily habit as newspapers, in addition to supplying news, provide their readers with a range of information on many subjects such as entertainment, health or education. For some people, namely students and language learners, newspapers are valuable for other reasons too. With their wide variety of text types and language styles, newspapers and social media are a good basis for language study which language learners will not find in conventional language learning materials and which will help them to be familiar with, and use many different communicative skills. (Koh, 2004). Social media is redefined as how humans are related to each other and to the organizations that serve them. It brings people together to discover and share information (Solis, 2008).

Study of media language usually begins with an interest in the language of a specific genre. According to Bell (1991), Burnett and Merchant (2011), one of the things that make newspapers attractive for language study is the wide variety of genres that one finds in them. Genre specificity, thus, within the page of newspapers is so significant that any attempt to replicate newspaper language without being aware of it can become misleading (Jackson, 2011).

In recent years, genre and genre-based pedagogy in language teaching has been emphasized. Genre-based instruction involves teaching students how to organize a text (Hyland, 2007) by identifying the moves and strategies (Hyon, 2001) within a particular setting (Swales, 1993). As the move structure of a genre might be hidden from foreign language (L2) learners, thus many ESP (English for Specific Purposes) specialists contend that move analysis should be taught to L2 learners as it might lead to the production of texts that better meet readers' expectations (Crossley, 2012). In this sense, teachers can help students develop new generic schema by assisting them in learning the patterns of language required in various academic contexts (Conteh \& Toyoshima, 2005).

With regard to the benefits of genre knowledge, however, the question of how genre is to be taught is one of the 
most enduring controversies in various educational contexts. Some educators such as Anthony (2000), Hammond and Derewianka (2001) disagree on the possibility and usefulness of genres to be taught explicitly. On the other hand, Bhatia (2001) and Widodow (2006), believe that genres have regularities and teacher explicitly provides students with guided practice as they develop language skills for meaningful communication.

Despite such wide range of opinions regarding the teaching of genres through explicit or implicit methods in an English as foreign language (EFL) context, there have been few experimental studies on the effects of these different teaching treatments. In order to establish a solid base for the genre-based instruction in the EFL curriculum, the purpose of the present study was to examine the effect of traditional (explicit, and implicit) and new techniques of (self-study and task-based) genre-based pedagogy of one type of newspaper genre, classified ad, on English juniors in Mobarakeh a distance educational system.

Distance education is a kind of education implemented in Iran by Payame Noor University (PNU). It is in both semi-attendance and self-study modes. Students, through the self-study mode, select their units and take the final exams without having any classes. Within the semi-attendance mode, students are provided with a few number of sessions at which their attendance is optional. Within this mode, the professors of PNU have two different methods of teaching, traditional and non-traditional. In the former way, the instructors teach directly (explicitly) the content of the text and in the non-traditional way, they ask their students to read the book by themselves and ask their questions, or in some cases they ask their students to perform a task.

Based on the data retrieved from the Internet, there have not been any studies comparing traditional and non-traditional techniques of teaching of one type of newspaper genre, classified ad, using quantitative analytic tools. Thus, there is a pressing need for unraveling the advantages and disadvantages of the traditional and new techniques between past, present and future for teachers and students. Therefore, the basic query of this study is comparing different educational techniques which is the main concern of English Language Arts (ELA). The present study is to answer the following question:

1) Are there any significant differences between the effects of traditional and non-traditional ways of teaching, namely; implicit, explicit, self-study and task-based instructions on learners' achievement of lexical and discourse features in writing classified ads?

The following hypothesis is made based on the research question:

2) There are significant differences between the effects of traditional and non-traditional ways of teaching, namely; implicit, explicit, self-study and task-based instructions on learners' achievement of lexical and discourse features in writing classified ads.

\section{Literature Review}

To better formulate a framework for the present study, this part will review genre-based, task-based instructions, and also a brief explanation of classified ad research.

\subsection{Review of Genre-Based Instructions}

The efficacy of genre based instruction has been explored in both L1and L2 contexts. In brief, Henry and Roseberry (1998) put forward that genre-based instruction does not improve the learner's ability to produce effective tourist information texts in the absence of explicit instruction. From a different perspective, Kay and Dudley-Evans (1998) held that a genre-based approach allows students to make sense of the world around them. Pang's (2002) study provided evidence for the fact that genre instruction enhances students' employment of move structures. Swami's (2008) study expressed that explicit instruction provides the students with a concrete opportunity to acquire conceptual and cultural frameworks to undertake writing tasks. More to the point, in Japan, Mizumoto and Takeuchi (2009) show evidence of the effectiveness of explicit instruction of vocabulary learning strategies. In the final analysis, Bacha's (2010) study is considered a successful attempt in providing needed explicit instruction for students in an EFL environment. Chen and Su's (2011) study is directly related to investigate the instructional efficacy of a genre-based approach to teaching summary writing. They take the view that such an approach was effective in improving students' overall performance of writing. Likewise, Gu (2011) took the stand that the explicitly instructed group showed greater progress in gaining pragmatic knowledge in on-line communication contrasting the implicit instructed group. Lee (2012) suggests that genre can be used as an organizational principle to make writing easier for students to learn. Inconsistent with the previous studies, Yeganeh, Ghoreyshi, and Darabi (2013) findings revealed that there wasn't a significant difference between explicit and implicit instructions and for more complex structure, implicit instruction was recommended. By contrast, Kia and Salehi's research (2013) provides evidence for the superiority of the explicit teaching over the implicit teaching. 
With regard to the reviews of recent genre literature, it is worth pointing out that most studies have been comparing traditional techniques of teaching; explicit and implicit instructions and just focused on one skill, writing or reading not the integration of both. It is also important to recall that although genre-based approaches have been implemented in several EFL classes, no empirical studies have been done to investigate the impact of explicit, implicit, self-study and task-based writing instruction on the classified ads genre on the learners' awareness of lexical and discourse structure.

\subsection{Review of Task-Based Instructions}

Because of problems with traditional approaches and methods of English language teaching (ELT) classrooms, Task-Based Learning (TBL) has been the focus of the attention of many L2 language instructors in the language teaching in the recent years (Richards \& Rodgers, 2001) mainly because it fosters social interaction, real communication, and acquisition of implicit knowledge (Ellis, 2003, 2009). Nevertheless, because of the difficulty in the implementation of the method in the classroom, the experimental research on task-based research has been poor (Sanchez, 2004), however examples of research demonstrating that tasks can be linked to language acquisition issues using an experimental research design are mentioned as follows.

Pica (2005) reveals the effectiveness of the tasks in drawing students' attention to form, function, and meaning in ways that are considered vital to students' L2 learning. Similarly, Fuente (2006) suggests that a task-based lesson with an explicit focus-on-forms component is more effective than a task-based lesson that does not incorporate this component. Moreover, Bantis (2008) shows that task based instruction can be a useful vehicle for differentiated instruction and constructivist pedagogy. Admittedly, Rahimpour (2008) argues that task-based instruction creates more favorable conditions and facilitates L2 acquisition. Moreover, Birjandi and Malmir's (2009) study gives voice to the interactive nature of the task-based approach where language use and language learning take place simultaneously. Similarly, Cubillo and Brenes (2009) show that both learners and teachers will benefit from a task-based approach. Yet precisely, Sharma (2011) expresses that for effecting smooth transition from grammatical knowledge to communicating use of language, a language teacher has to think of task based teaching. Generally speaking, Poorahmadi (2012) indicates that classroom tasks can be very helpful in accelerating students' language learning development because they can engage learners in using language pragmatically rather than displaying language.

As the literature reviewed indicates, task-based instruction has attracted many researchers' attention and has been used in EFL classes in the last decade. However, one notices that there have been no studies to examine the effect of four instructional techniques on the ability of EFL students to produce a classified ad. In fact, Ellis (2009) expresses that there remains a dearth of comparative studies of TBI and other forms of instruction. Hence, the present study could be considered as a contribution to this line of research.

\subsection{Classified Ad Writing}

It is important to note that there are a lot of researches which have examined how different countries and regions vary in their forms of advertising (Roberts \& Ko, 2001), on the other hand; research on the classified ads writing has been scarce. Among representative studies of the language of classified advertising is Vaičenoniene (2006) who analyzed the language of advertising in English and Lithuanian in order to estimate the specificities of the advertising genre in the two different cultural and linguistic systems. In a similar study Stroeva (2013) compared text pragmatics in English and Russian classifieds. In particular, in a detailed analysis of the language of the classified ads, Pop (2007) argued that the language of this genre resorts to a minimal syntactic elaboration, even a syntaxless and paratactic grammar.

Based on the data retrieved from the Internet and ProQuest database, there have been no empirical studies that have used classified ads to examine the effects of different teaching approaches, namely: impact of explicit, implicit, self-study and task-based writing instruction on the learners' awareness of the classified ad genre in English L2 contexts, Indeed, Koh (2004), confirms that little is known and written about newspaper literacy in the classroom, as such the classified ad was used in the present study to contribute to this line of research.

\section{Methodology}

This study adopts a quasi- experimental, pre-test, treatment and post-test design.

\subsection{Participants}

There were 98 juniors at Mobarakeh PNU who enrolled for the Reading Journalism course during the 2013 academic year. The participants of the study were streamed regarding their general language proficiency through TOEFL test. This procedure led to the selection of 72 homogeneous subjects. Subsequently, the researcher randomly assigned the subjects into the four groups, namely, explicit $(N=18)$, implicit $(N=18)$, task-based $(\mathrm{N}==18)$ 
and self-study $(N=18)$.

The mean and the standard deviation of the subjects' test scores $(M=24$ out of $50, S D=3.2)$ were used as the criterion for their selection. This homogenous sample had ages ranging from 18 to $32(M=21.5, S D=.79)$, with 62 women and 10 men. In the beginning of the study, the participants were informed about the purpose of the study and each participant was given a consent form that they were required to read and sign.

\subsection{Administering the Pre- and Post-Tests}

The subjects of the four groups were asked to write an English classified ad which was used as the pre-test. The pre-test was administered to evaluate the subjects' writing ability about the classified ads structure before the treatment. At the end of the treatment, the four groups were asked to write a classified ad to see the effect of the instruction (Appendix 1).

\subsection{Model Texts}

All the groups were given the same model texts. The classified ads structure of the model texts were similar, straightforward, and easily identified, and the texts had similar lengths.

\subsection{Procedure}

The treatment took place during the second semester of the academic year 2013. In the present study, there were four groups- an explicit group which received explicit instruction of the classified structure, an implicit group which was instructed implicitly, and the task-based group who were just asked to prepare a classified ad and the self-study group which received no-instruction treatment regarding the lexical and discourse features of the classified ads.

All the subjects attended a total of two separate sessions (on Saturday and Wednesday). Each session lasted 90 minutes. The experiment was restricted to two sessions in order to make sure that any significant differences in performance of the participants in writing classified ads could be attributed to the treatment as far as possible.

\subsubsection{The Explicit Group}

The approach which was used for all the four groups in this study was based on the model developed by Hyland (2007) who believes that teaching based on genre approach is consisted of four stages, namely: modeling, joint construction, independent construction, and comparing. For the instruction of the lexical and discourse features of the classified ads, (modeling stage), one instructional session was held and for the practice of writing classified ads (joint construction, independent construction and comparing), one practice session was held.

In the instructional session, the researcher exposed the subjects to the models of the classified ad. During the instruction, the subjects were familiarized with the classified ad structure. This included reading classified ad model texts. The instructor explained each lexical feature, its function, and the linguistic forms used in it.

Following the instructional session, participants in the explicit condition participated in the practice session. During that session, first, the participants were asked to write a classified ad co-operatively. Then the subjects were asked to write their own classified ad individually. In the last stage, they compared the classified ads with other ads and talked about their differences.

\section{Explicit instructional session}

- $\quad$ Reading the models

- Teaching new vocabulary items, the meanings of abbreviations and grammar of the ads

- Providing learners with practice to analyze the structure of the models

- Practicing classified ad elements and comparing it with advertisements

\section{Practice session}

- Composing jointly

- Giving feedback

- composing independently

- Drafting

- Giving feedback

- Revising and editing

- Comparing 


\subsubsection{The Implicit Group}

The participants of the implicit group received the same model texts. The participants did not receive explicit instruction about classified ad structure. They were introduced to the first classified ad and were asked questions such as:

- What is this text about?

- What is the purpose of the text?

- How many bedrooms does the apartment have?" "How much is the rent?" "Where is it located?" and what features it has. Which apartments look expensive? How do you know? Etc.

Following this session, the students participated in one practice session. First, the participants constructed a classified ad jointly then individually. Their classified ads were read by the researcher and their errors were corrected. At the end, they compared their ads with other kinds of ads.

\section{Implicit instructional session}

- $\quad$ Reading the models

- Asking comprehension questions

- $\quad$ Providing learners with practice to ask questions

\section{Practice session}

- Composing jointly

- Giving feedback

- Composing independently

- Drafting

- Giving feedback

- Revising and editing

- Comparing

\subsubsection{The Self-Study Group}

The self-study subjects received the same treatment except modeling stage (instruction). The self-study group had studied the model texts as homework on their own without any researcher's explicit or implicit instruction.

In one session, the models were given to the participants of the self-study group and were asked to read them for the practice session. In that session, the class started with reviewing and eliciting students' background knowledge about the classified ads models to see whether the students had studied the model ads or not.

\section{Practice session}

- Eliciting subjects' background knowledge about the models

- Composing jointly

- $\quad$ Giving feedback

- Composing independently

- Drafting

- Giving feedback

- Revising and editing

- Comparing

\subsubsection{The Task-Based Instruction Group}

The task-based subjects received the same genre-based writing cycle except the modeling stage. During the first session, the participants of this group were asked to form groups of three which resulted in six groups. Then the classified ad models were given to each group and they just were asked to read the models and write a well classified ad that promotes their house and can attract interest from people. They were required to bring the classified ad for the next session.

In the next session, first all the groups were asked to read their classified ads in class for comments. After that they were asked to write a classified ad individually. Their classified ads were read by the researcher and their 
errors were corrected.

\section{Session 1}

- Grouping the participants

- Giving them the models

- Telling them they are to write a classified ad

- Telling them to use the models as guide

\section{Session 2}

- Asking the groups to present their ads to the class

- Giving feedback

- Composing independently

- Drafting

- $\quad$ Giving feedback

- $\quad$ Revising and editing

- Comparing

\subsection{Scoring Procedure}

The data used for the analysis were 144 English classified ads produced by the participants of the four groups at the end of the treatment. In order to determine inter-rater reliability, the researcher worked with another rater, an experienced EFL instructor. The classified ads were scored independently as well as analytically by the researcher and the colleague rater.

\subsubsection{Model of Analysis}

\section{- $\quad$ Lexical features}

Given that the space is limited, articles, verbs, pronouns, conjunctions, words, and prepositions are left out in English classified ads. Since the price of many classified ads is determined by the number of words, abbreviations are used so that realtors can give more information about their houses in less space (Bell, 1991; Pop, 2007).

For example (The omissions and abbreviations are shown in parentheses.):

(There is an apartment on) Sajad (street), (It is) 200sq.m (square meter), (It has) 3bdrs (bedrooms), 3 svcs (services), 2 balconies (a) Marble Fl. (floor), (a)Fpl (Fireplace), (a) Closed kit. (Kitchen), (It is) F.F. (Fully furnished), (and) (It has) (a) covered PL (parking lot), (The rent is) \$1400(each month)

(call) Mr. Ebadi

\section{- Discourse analysis}

Discourse analysis is typically defined as the analysis of language beyond the sentence (Cook, 1992). This implies that it takes the context into account in order to understand how it affects the meaning of the sentence. The discourse features of a classified advertisement consists of three parts as follows:

\section{What $R U$ waiting $4 \ldots ! \quad \longrightarrow$ Headline}

\section{Zaferanieh}

100 sq.m, 3bdrs, 2svcs, marble FL.,

Fireplace, Sauna, Jac., covered pkg. F.F. , only $\$ 5000$

\section{Mr. Andy $\longrightarrow$ the call to action}

\subsection{Error Analysis}

The analysis of errors in lexical and discourse features category was done according to the following subcategories, namely: wrong translation of the vocabularies, lack of use of the abbreviations, redundant use of the verbs, nouns, prepositions, pronouns, and wrong choice of the discourse features of the ads:

The following example is drawn from one the participants' pre-tests.

Mr Andy has a house in the street Freshteh, call him and he tell you the house which is one four hundred long and there are two bedrooms in the house and the floor is made of stone and there is a pool in the house and the 
kitchen is close and it has a wall and there is a jacozi and the house has tables and sofa and everything is in the house and there is a parking in the house and the house is in Freshteh street, and the rent is 13000 dollars.

\section{Results}

The raw data taken from the English pre- and post -classified ads were first examined for the assumption of normal distribution and homogeneity of variance.

Table 1. Test of normality

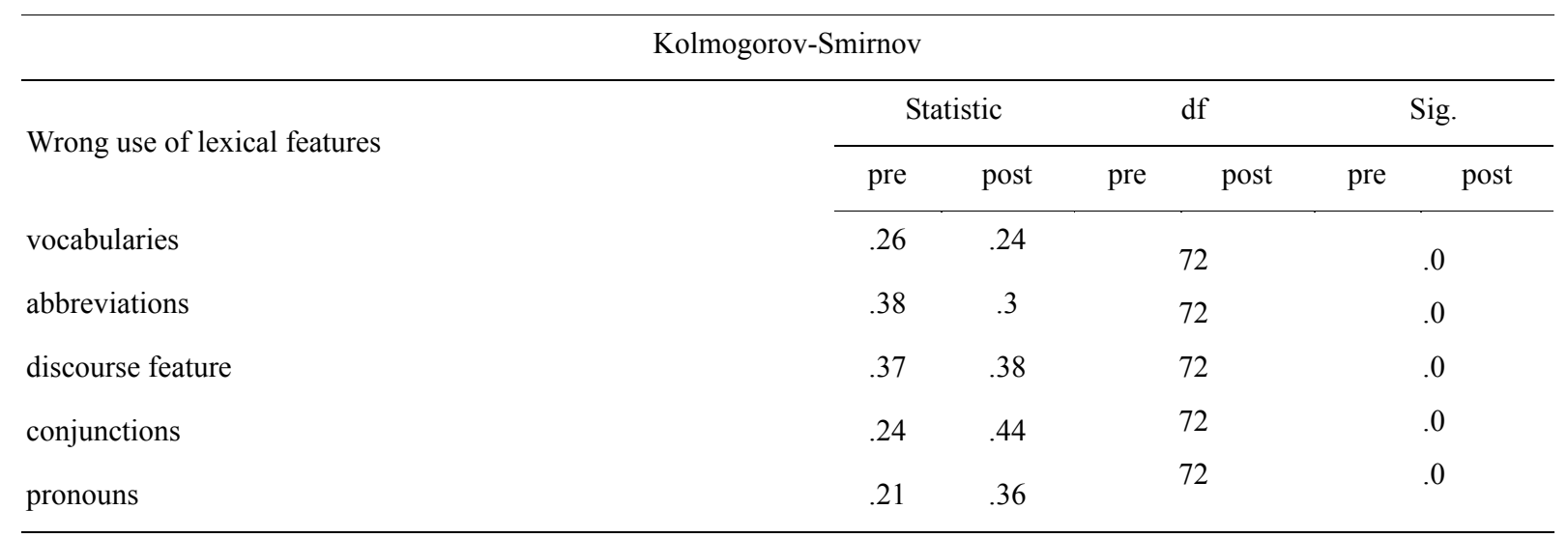

The observed values of English pre- and post- classified ads obtained by Kolmogorov-Smirnov are .00 which are smaller than critical value at 0.05 level of significance and it proved that the distributions of the data were not normal $(p=.00)$, as it can be seen in Table 1 .

In order to analyse the correct use of conjunctions, vocabularies, abbreviations, discourse feature, and pronouns in the English pre- and post- papers, the frequencies of the wrong use of these elements in each student's pre- and post- papers were tallied. The scores were calculated to determine the mean scores and standard deviation.

Table 2. Observed frequency of the errors

\begin{tabular}{|c|c|c|c|c|c|c|c|c|c|c|c|}
\hline \multicolumn{2}{|c|}{ Groups } & \multicolumn{2}{|c|}{ Vocabularies } & \multicolumn{2}{|c|}{ abbreviations } & \multicolumn{2}{|c|}{ discourse } & \multicolumn{2}{|c|}{ Conjunctions } & \multicolumn{2}{|c|}{ pronouns } \\
\hline & & pre & post & pre & post & pre & post & pre & post & pre & post \\
\hline \multirow{2}{*}{ Explicit } & Mean & 2.7 & .5 & 9.7 & .5 & 8.8 & .0 & 1.8 & .1 & 2.5 & .1 \\
\hline & Std. Deviation & 1.2 & .7 & 1.1 & .6 & 2.1 & .2 & 1.2 & .3 & 1.7 & .3 \\
\hline \multirow{2}{*}{ Implicit } & Mean & 2.5 & 2 & 9.9 & 3 & 8.6 & .8 & 1.5 & .3 & 2.2 & .7 \\
\hline & Std. Deviation & 1.0 & .9 & 1.1 & 2 & 2.0 & .7 & 1.2 & .5 & 1.5 & .9 \\
\hline \multirow{2}{*}{ Self-study } & Mean & 2.2 & 2 & 10.1 & 7.2 & 9.1 & 6.9 & .8 & .7 & 2 & 1.2 \\
\hline & Std. Deviation & 1.1 & 1.1 & .676 & 3 & 1.8 & 3.8 & 1.0 & .8 & 1.6 & 1.4 \\
\hline \multirow{2}{*}{ Task-based } & Mean & 2.6 & .2 & 10.2 & .2 & 9.9 & .3 & .8 & .0 & 2.6 & .1 \\
\hline & Std. Deviation & 1.2 & .4 & .42 & .4 & .5 & .4 & .9 & .0 & 1.3 & .3 \\
\hline \multirow{2}{*}{ Total } & Mean & 2.5 & 1.2 & 10 & 2.8 & 9.1 & 2 & 1.2 & .3 & 2.3 & .5 \\
\hline & Std. Deviation & 1.1 & 1.2 & .8 & 3.6 & 1.8 & 3.4 & 1.1 & .6 & 1.5 & 1 \\
\hline
\end{tabular}

As seen in Table 2, the average number of errors in the use of abbreviations in the pre-test papers of the explicit, the implicit, the self-study and task-based groups was 9, 9, 10, and 10 respectively. The average number of the errors in the use of abbreviations per English post-test paper across the explicit, the implicit, the self-study and 
the task-based group was $0.5,3,7$, and .2 respectively.

To find out if there were any differences between the groups, Kruskal-Wallis Test was employed.

Table 3. Kruskal-Wallis test, test statistics

\begin{tabular}{|c|c|c|c|c|c|c|c|c|c|c|}
\hline \multicolumn{7}{|c|}{ Pre-test } & \multicolumn{4}{|c|}{ Post-test } \\
\hline & \multicolumn{10}{|c|}{ vocabulary abbreviation discourse conjunctions pronouns vocabulary abbreviation discourse conjunction pronoun } \\
\hline Chi-Square & 1.7 & 3.1 & 5.9 & 9.3 & 1.8 & 41.1 & 39.5 & 35.3 & 16.0 & 19.9 \\
\hline df & 3 & 3 & 3 & 3 & 3 & 3 & 3 & 3 & 3 & 3 \\
\hline $\begin{array}{c}\text { Asymp. } \\
\text { Sig. }\end{array}$ & .62 & .36 & .11 & $.02 *$ & .59 & $.0^{*}$ & $.0^{*}$ & $.0^{*}$ & $.0^{*}$ & $.0^{*}$ \\
\hline $\begin{array}{c}\text { Partial Eta } \\
\text { Squared }\end{array}$ & .01 & .04 & .07 & .13 & .02 & .52 & .6 & .6 & .2 & .2 \\
\hline $\begin{array}{c}\text { Observed } \\
\text { Power }\end{array}$ & .1 & .2 & .4 & .7 & .1 & .9 & .9 & .9 & .9 & .9 \\
\hline
\end{tabular}

The $p$-value for the use of lexical and discourse features in the post-classified ad was .0 which was less than the significance level set for the study (0.05), consequently, the groups were different.

To find out if there were any differences within the pre- and post-classified ads, Wilcoxon test was employed.

Table 4. Wilcoxon test, mean rank

\begin{tabular}{|c|c|c|c|c|c|c|c|c|c|c|}
\hline & \multicolumn{2}{|c|}{ vocabulary } & \multicolumn{2}{|c|}{ abbreviation } & \multicolumn{2}{|c|}{ discourse } & \multicolumn{2}{|c|}{ conjunction } & \multicolumn{2}{|c|}{ pronoun } \\
\hline & post & pre & post & pre & post & pre & post & pre & post & pre \\
\hline Mean Rank & 198 & 3.5 & 34 & 3 & 3.3 & 19 & 22 & 9 & 25 & 8.5 \\
\hline Sum of ranks & 696 & 7 & 2272 & 6 & 2192 & 19 & 816 & 45 & 1208 & 17 \\
\hline
\end{tabular}

Table 4 shows that in the use of lexical and discourse features in the pre- and post-classified ads, the $p$-values (.00) were less than 0.05 , which means that there were significant differences within the participants.

Table 5. Wilcoxon test, test statistics

\begin{tabular}{|c|c|c|c|c|c|}
\hline & $\begin{array}{c}\text { vocabularies } \mathrm{p} \\
\text { pre }\end{array}$ & $\begin{array}{l}\text { eviations post } \\
\text { - pre }\end{array}$ & $\begin{array}{l}\text { discourse feature } \\
\text { post - pre }\end{array}$ & $\begin{array}{l}\text { conjunctions post } \\
\text { - pre }\end{array}$ & $\begin{array}{c}\text { pronouns post - } \\
\text { pre }\end{array}$ \\
\hline Z & $-5.283^{\mathrm{a}}$ & $-7.125^{\mathrm{a}}$ & $-6.976^{\mathrm{a}}$ & $-5.067^{\mathrm{a}}$ & $-5.981^{\mathrm{a}}$ \\
\hline Asymp. Sig. (2-tailed) & $.000 *$ & $.000 *$ & $.000 *$ & $.000 *$ & $.000^{*}$ \\
\hline Partial Eta Squared & .420 & .795 & .786 & .356 & .512 \\
\hline Observed Power & .999 & .999 & .999 & .999 & .999 \\
\hline
\end{tabular}

Since the significance value .0 was less than the significance level of .05 , it was concluded that there were significant differences between the groups in the use of lexical and discourse features in the pre- and postclassified ads.

\section{Discussion}

Regarding the students' English pre-classified ads, the results of the research indicated that the participants of the four groups had lexical and discourse errors in their ads. Most errors were caused by wrong translation of 
vocabularies, redundant use of pronouns, verbs, prepositions, articles, nouns, conjunctions, and faulty discourse feature choice.

The analysis of the pre-tests showed that the participants had inadequate knowledge of the English classified ads rules. In their ads, the participants wrote simple sentences by using the articles, conjunctions, prepositions, verbs, pronouns, and copula instead of omitting them. The analysis also revealed that the explicit, implicit, self-study and task-based participants tended not to include any abbreviations in their pre-tests. Through the lenses of contrastive rhetoric, it becomes clear that the students in each group lacked explicit knowledge of how to write a classified ad because they had not been taught explicitly how to do so in their L2 classes. When writing does not exhibit elements of composition, it is negatively regarded as disorganized and incoherent (Silva, 1990). Regarding this line of argument, it proves that the four groups' English pre-classified ads are disorganized as their papers lack lexical and discourse features.

Regarding the participants' English post-classified ads, the groups were different in terms of their use of lexical and discourse features. The quantitative analysis of the pre -and post-classified ads revealed that the participants of the explicit and task-based groups, in general, used the lexical and discourse features in their post classified ads which were absent in their pre-tests.

Despite the short amount of instruction on the genre classified ads and based on the pre- and the post-tests, the explicit and task-based groups showed a marked improvement as compared to the implicit and self-study groups. These results reveal the potential of explicit genre-based writing instruction for the explicit participants' writing improvement, which are in line with Mizumoto and Takeuchi (2009), Gu (2011), and Kia and Salehi (2013) who debate the usefulness of explicit over implicit teaching methods and find that the former gives better results in terms of student writing development. Thus, explicit teaching of classified ads genre which focuses on the lexical and discourse features of the classified ads would help students acquire the rules. Since 1990s, some researchers put forward the idea that focusing students' attention on form, mainly through explicit instruction, is superior to implicit teaching (Abbuhl, 2011; Kia \& Salehi, 2013).

The quantitative analysis of the post-classified ads revealed that the participants of the task-based group outperformed the participants of self-study and the implicit groups in the use of lexical and discourse features of the classified ads. This result reveals the potential of model texts combined with preparing classified ads for the task-based participants' writing improvement, which is in line with Bantis (2008), Birjandi and Malmir (2009) and Rahimpour (2008). The results of this research contradicts Bygate (2001) who argues that use of tasks alone cannot promote learning, so tasks must be incorporated systematically into a curriculum. As seen, the use of task alone in this study enhanced language learning so tasks can be used as the key element in a pedagogic cycle. According to Ellis (2003), the communicative, meaning-centered, and authentic nature of the task-based approach helped the participants of this group outperform. Likewise, McNicoll and Lee (2011) are a proponent of the view that that lower-proficiency-level learners may benefit more from concrete tasks. This meant above all that a task is an activity in which students are engaged in to attain an objective, and which involves them to use the language meaningfully (Bygate, Skehan, \& Swain, 2001).

It is worth pointing out that cooperative and interactive nature of the task-based approach where language use and language learning take place simultaneously (Birjandi \& Malmir, 2009) helped the outperformance of the task-based group. In this group, the participants prepared their classified ad in groups of three, so they received feedback from their peers in their own and other groups, and in the practice session received feedback from the instructor. The results are in line with the concept of Zone of Proximal Development (ZPD) (Vygotsky, 1978) which approves the importance of effective support (Hammond, 2006) and which believes that learning in an L2 context should be a cooperative and not an isolated individual's effort where the learner works unassisted and unmediated (Turuk, 2008).

Although the control group was not exposed to the explicit instruction, results show that lexical and discourse features were also found in the control group post- classified ads and it proves that the implicit genre-based teaching method was better than the self-study instruction method and it is in line with Yeganeh et al's study (2013) who showed that implicit genre instruction did enhance students' employment of move structure.

Regarding the self-study group's results, the findings show that almost none of the participants of self-study were able to present the elements of lexical and discourse features in their English classified ads which prove that no-instruction is insufficient for L2 students and that explicit or task-based instructions can facilitate students' noticing and use of classified ad features. The results show that classified ad elements were difficult for the self-study group to learn by themselves without instruction. 
There were some limitations of this study which needed to be focused on. First, the scope of the present study both in terms of its content and the population was limited. Another limitation of the present research was the use of the teaching learning cycle developed by Hyland (2007), also more investigation should be made with the use of other genre-based approaches. As distance education emphasizes on learner independence and less reliance on training materials, so teachers and students can examine the emergence of social media and social learning and study their pros and cons for the future of English education. As PNU suffers from extensive educational challenges in terms of quality and access; so the educators, and the students can rely on social media tools to create innovative approaches to English education, transfer of knowledge and peer-to-peer learning.

Social media has many different forms including magazines, weblogs, social blogs, Internet forums, photographs, video, etc. Future research could benefit from analysis of the effects of the growth of social media and its implications in the society. Other promising areas for future studies include evaluation of the effectiveness of social media as a tool of English education. The participants and duration of the study were also limited. Future studies that involve a larger number of participants with an expanded period of time would be significant contribution to the field. As PNU offers limited number of classes to the students, there is a pressing need for PNU students to acquire the English writing in a short period of time. Given the positive learning outcomes of the use of explicit and task-based approaches, it would be valuable to implement such approaches in PNU and determine their usefulness across universities.

\section{Conclusion}

The basic query of this study was comparing different educational techniques which is the main concern of ELA. The aim of this study was mainly to examine the impact of one kind of social media use in education namely classified ads writing and compare the effects of the four different instructions of classified ads writing including explicit, implicit, self-study and task-based instructions.

Regarding the comparison of English pre -and post-classified ads, the results are particularly encouraging for the explicit and task-based groups. These groups actually made greater gains on most of the categories assessed on their English post- classified ads. Explicit instruction is characterized by clear descriptions of linguistic and lexical features, followed by practice and feedback, whereby in the task-based class students learn a language by performing tasks. Students achieved more in explicit and task-based classes in which they were being directly taught by their instructor or performed a task. It is argued that both explicit and task-based instructions create more favorable and better conditions for the development of second language ability than the self-study and implicit approaches.

Some potential pedagogical implications for classified ad writing instruction can be drawn from the findings above. Considering the type of treatment, the post-test results showed that explicit and task-based instruction assisted the explicit and task-based groups to outperform the other groups. One such implication appears the most obvious for the future of English education. Explicit and task-based instructions were particularly effective in assisting students to learn about lexical and discourse elements of classified ads.

Obviously, teachers should take advantage of different approaches and techniques and combine them to help learners improve their skills (Cubillo \& Brenes, 2009). As a result, by asking students to do a task, they will benefit from a different approach because it is more motivating, and more meaningful (Ellis, 2003) than other traditional instruction-based approaches. Task-based approach seems to be the best methodology for teaching in PNU as it is a distance education system which has not yet provided its distance education with electronic facilities. As task-based instruction is quite interactive, it allows students of PNU follow the principles of cooperative learning (Ellis, 2003). According to Ellis (2009), task-based instruction is suitable for acquisition-poor environments where communication opportunities cannot be found in the community and task-based instruction is a means of achieving this (p. 238).

\section{References}

Abbuhl, R. (2011). Using models in writing instruction: A comparison with native and nonnative speakers of English. SAGE Journals, 1(3), 1-12. http://dx.doi.org/10.1177/2158244011426295

Anthony, L. (2000). Implementing genre analysis in a foreign language classroom. TESOL Matters, 10 (3), $18-24$.

Bacha, N. (2010). Teaching the academic argument in a university EFL environment. Journal of English for Academic Purposes, 9, 229-241. http://dx.doi.org/10.1016/j.jeap.2010.05.001

Bantis, A. (2008). Using Task Based writing Instruction to provide differentiated instruction for English language learners (Master's Thesis). Retrieved from ERIC database on 1/3/2014. (ED504698) 
Baruah, T. D. (2012). Effectiveness of social media as a tool of communication and its potential for technology enabled connections: a micro-level study. International Journal of Scientific and Research Publications, 2(5).

Bell, A. (1991). The language of news media. Oxford: Blackwell.

Bhatia, V. (2001). The power and politics of genre. In A. Burns, \& C. Coffin (Eds.), Analyzing English in a global context: A reader (pp. 65-77). London: Routledge.

Birjandi, P., \& Malmir, A. (2009). The effect of task-based approach on the Iranian advanced EFL learners' narrative vs. expository writing. The Iranian Journal of Applied Language Studies, 1(2), 1-26.

Burnett, C., \& Merchant, G. (2011). Is there a space for critical literacy in the context of social media? English Teaching: Practice and Critique, 10(1), 41-57.

Bygate, M., Skehan, P., \& Swain M. (2001). Researching pedagogic tasks: Second language learning, teaching and testing. London, UK: Longman.

Bygate, M. (2001), Effects of task repetition on the structure and control of oral language. In M. Bygate, P. Skehan, \& M. Swain, (Eds.), Researching Pedagogic Tasks: Second Language Learning, Teaching and Testing. Harlow: Longman.

Chen, Y., \& Su, Sh. (2011). A genre-based approach to teaching EFL summary writing. ELT Journal, 66(2), 184-192. http://dx.doi.org/10.1093/elt/ccr061

Conteh, J., \& Toyoshima, S. (2005). Researching teaching and learning: Roles, identities and interview processes. English Teaching: Practice and Critique, 4(2), 23-34.

Cook, G. (1992). The Discourse of Advertising. London and New York: Routledge.

Crossley, S. A. (2012). The effects of genre analysis pedagogy. Retrieved from http://www2.gsu.edu/ wwwesl/Files/ALSL/crossley_flsp.pdf

Cubillo, P. C., \& Brenes, C. N. (2009). Using task-based instruction in an ESP course in the computer center at the University of Costarica. Actualidades Investigativas en Educación, 9(1), 1-25.

Ellis, R. (2003). Task-based language learning and teaching. Oxford: Oxford University Press.

Ellis, R. (2009). Task-based language teaching: Sorting out the misunderstandings. International Journal of Applied Linguistics, 19(3), 221-246. http://dx.doi.org/10.1111/j.1473-4192.2009.00231.x

Fuente, M. J. (2006). Classroom L2 vocabulary acquisition: Investigating the role of pedagogical tasks and form-focused instruction. Language Teaching Research, 10(3), 263-295. http://dx.doi.org/10.1191/1362168806lr196oa

Gu, X.-L. (2011). The effect of explicit and implicit instructions of request strategies. Intercultural Communication Studies, 20(1), 104-123.

Hammond, J. (2006). High challenge, high support: Integrating language and content instruction for diverse learners in an English literature classroom. Journal of English for Academic Purposes, 5, 269-283. http://dx.doi.org/10.1016/j.jeap.2006.08.006

Hammond, J., \& Derewianka, B. (2001). Genre. In R. Carter, \& D. Nunan (Eds.), The Cambridge Guide to Teaching of English to Speakers of Other Languages (pp. 186-193). New York: Cambridge University Press. http://dx.doi.org/10.1017/CBO9780511667206.028

Henry, A., \& Roseberry, R. L. (1998). An Evaluation of a genre-based approach to the teaching of EAP/ESP writing. TESOL Quarterly, 32(1), 147-156. http://dx.doi.org/10.2307/3587913

Hyland, K. (2007). Genre pedagogy: Language, literacy and L2 writing instruction. Journal of Second Language Writing, 16, 148-164. http://dx.doi.org/10.1016/j.jslw.2007.07.005

Hyon, S. (2001). Long-term effects of genre-based instruction: A follow-up study of an EAP reading course. English for Specific Purposes, 20, 417-438. http://dx.doi.org/10.1016/S0889-4906(01)00019-9

Jackson, F. M. (2011). Local appropriation of global communication forms: A micro case study of teacher and learners' uses of mass media genres. English Teaching: Practice and Critique December, 10(4), 58-74.

Kay, H., \& Dudley-Evans, T. (1998). Genre: what teachers think? ELT Journal, 52, 308-314. http://dx.doi.org/10.1093/elt/52.4.308

Kia, E., \&, Salehi, M. (2013). The effect of explicit and implicit instruction of English thanking and 
complimenting formulas on developing pragmatic competence of Iranian EFL upper- intermediate level learners. Journal of Basic and Applied Scientific Research, 3(8), 202-215.

Koh, A. (2004). Newspaper literacy: An investigation of how Singaporean students read the Straits Times. English Teaching: Practice and Critique, 3(3), 43-60.

Lee, I. (2012). Genre-based teaching and assessment in secondary English classrooms. English Teaching: Practice and Critique, 11(4), 120-136.

Malihah, N. (2010). The effectiveness of speaking instruction through task-based language teaching. Register, $3(1), 85-101$.

McNicoll, J., \& Lee, J. H. (2011). Collaborative consciousness-raising tasks in EAL classrooms. English Teaching: Practice and Critique December, 10(4), 127-138.

Mizumoto, A., \& Takeuchi, O. (2009). Examining the effectiveness of explicit instruction of vocabulary learning strategies with Japanese EFL University students. Language Teaching Research, 13(4), 425-449. http://dx.doi.org/10.1177/1362168809341511

Pang, T. T. T. (2002). 'Textual analysis and contextual awareness building: A comparison of two approaches to teaching genre'. In A. M. Johns (Eds.), Genre in the classroom. Mahwah, New Jersey: Lawrence Erlbaum Associates.

Pica, T. (2005). Classroom learning, teaching, and research: A task-based perspective. The Modern Language Journal, 8(9), 339-352. http://dx.doi.org/10.1111/j.1540-4781.2005.00309.x

Poorahmadi, M. (2012). Investigating the efficiency of task-based instruction in improving reading comprehension ability. Journal of language and translation, 3(1), 29-36.

Pop, A. (2007). Information density in classified advertising. Conferinta Internationala European Integration between Tradition and Modernity, Universitatea, Petru Major.

Rahimpour, M. (2008). Implementation of task-based approaches to language teaching. Foreign Languages Research (Pajohesh-e-Zabanhay-e- Khareji), Special Issue in English, Tehran University, 41, 45- 61.

Richards, J., \& Rodgers, T. (2001). Approaches and Methods in Language Teaching. Cambridge: Cambridge University Press. http://dx.doi.org/10.1017/CBO9780511667305

Roberts, M. S., \& Ko, H. (2001). Global interactive advertising: Defining what we mean and using what we have learned. Journal of Interactive Advertising, 1(2), 53-64. http://dx.doi.org/10.1080/15252019.2001.10722048

Sanchez, A. (2004). The task-based approach in language teaching. International Journal of English Studies, 4(1), 39-71.

Sharma, K. (2011). Task based teaching: Using modals for ESL learners. ELT Voices India, 1(45), 32-38.

Silva, T. (1990). Second language composition instruction: Developments, issues, and directions in ESL. In B. Kroll (Ed.), Second language writing: Research insights for the classroom (pp. 11-23). New York: Cambridge University. http://dx.doi.org/10.1017/CBO9781139524551.005

Solis, B. (2008). The essential guide to social media. Retrieved from http://www.briansolis.com/2008/06/essential-guide-to-social-media-free/

Stroeva, I. S. (2013). The pragmatic features of texts in classified advertisement in Russian and English languages. Middle-East Journal of Scientific Research, 17(4), 429-433.

Swales, J. (1993). Genre and engagement. http://dx.doi.org/10.3406/rbph.1993.3898

Swami, J. A. (2008). Sensitizing ESL learners to genre. ESL-EJ, 12(3), 1-13.

Turuk, M. Ch. (2008). The relevance and implications of Vygotsky's sociocultural theory in the second language classroom. ARECLS, 5, 244-262.

Vaičenonienè, J. (2006). The language of advertising: Analysis of English and Lithuanian advertising texts. Studies about Languages, 9, 43-55.

Vygotsky, L. S. (1978). Mind in society: The development of higher psychological processes. Cambridge, Massachusetts: Harvard University Press.

Widodo, H. P. (2006). Designing a genre-based lesson plan for an academic writing course. English Teaching: Practice and Critique, 5(3), 173-199. 
Yeganeh, M., Ghoreyshi, M., \& Darabi, R. (2013). The effect of explicit and implicit instruction on monolingual bilingual EFL learners and acquisition of L2 grammar. European Online Journal of Natural and Social Sciences, 2(2), 160-167.

\section{Appendix 1}

\section{Test}

Look at the following picture and write a classified ad for it.

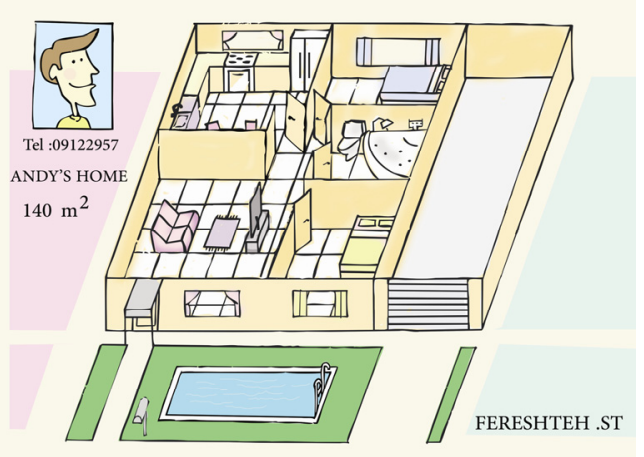

\section{Appendix 2}

Models

Your dream house!!!!!

Enghelab

$\$ 1300$

140 sq.m, 2bdrs, Marble F1., f/p, Closed kit.,Jac. F.F., pkg

Mr, Andy

We are caring more about $\mathrm{U}$.

Freshteh

110sqm, 2 bdrms, f.f. , 3 svcs, 2 balconies, FP., patio, green yard, F.f

$700 \$$

Paollo

What R U waiting 4...!

Zaferanieh

100 sq.m, 3bdrs, 2sves, marble FL.,

F.P., Sauna, Jac., covered pkg. F.F., only $\$ 5000$

Mr. Andy

Unbelievable!!!!!!!

Jordan,

$\$ 1200$

150 sq.m, 2bdrs, open kit., 2 full svcs, remote pkg., tel lines, stlt.

Mr. Hashemi 


\section{Copyrights}

Copyright for this article is retained by the author(s), with first publication rights granted to the journal.

This is an open-access article distributed under the terms and conditions of the Creative Commons Attribution license (http://creativecommons.org/licenses/by/3.0/). 